\title{
Mechanical Behavior of TiN/TiC-n Multilayer Coatings and Ti(C,N) Multi- component Coatings Produced by PACVD
}

\author{
M. Azadi, ${ }^{\text {a,1 }}$ A. S. Rouhaghdam, ${ }^{\text {b }}$ and S. Ahangarani ${ }^{\mathrm{c}}$ \\ ${ }^{a}$ Materials Engineering Department, Faculty of Engineering, Semnan University, Semnan, Iran \\ b Surface Engineering Laboratory, Materials Engineering Department, Faculty of Engineering, \\ Tarbiat Modares University, Tehran, Iran \\ c Advanced Materials and Renewable Energies Department, Iranian Research Organization for \\ Science and Technology, Tehran, Iran \\ 1 m.azadi@semnan.ac.ir
}

УДК 539.4

\section{Механические свойства многослойных TiN/TiC-n и многокомпонентных $\mathrm{Ti}(\mathrm{C}, \mathrm{N})$ покрытий при вакуум-плазменном химическом осаждении паров}

\author{
М. Азади", А. С. Рухагдам ${ }^{\circ}$, С. Ахангарани \\ a Университет г. Семнан, Иран \\ ${ }^{\sigma}$ Тарбиат Модарес университет, Тегеран, Иран \\ в Иранская научно-исследовательская организация науки и технологии, Тегеран, Иран
}

\begin{abstract}
Изучены механические свойства многослойных и многокомпонентных покрытий. Многослойное нитрид-титановое/карбид-титановое (TiN/TiC-n) и многокомпонентное Ti(C,N) покрытия наносили на поверхность горячеобработанной инструментальной стали AISI H13 посредством вакуум-плазменного химического осаждения паров при воздействии импульсного постоянного тока. Исследовань микротвердость, вязкость разрушения, разрушение при износе и коэффициент трения при испытаниях на твердость по Виккерсу и износ по схеме “диск-ипилька”. Подвергнутые износу поверхности и механизмы износа изучены с помошью оптического микроскопа. Результаты показывают, что многослойные покрытия TiN/TiC-10 имеют более низкие значения коэффициента трения $(0,2)$ и разрушения при износе и более высокие значения вязкости разрушения $\left(17,7 \mathrm{M \Pi а} \cdot \mathrm{M}^{1 / 2}\right)$ и микротвердости (3150 VHN) по сравнению с таковыми для многокомпонентного покрытия $\mathrm{Ti}(\mathrm{C}, N)$ и других исследованных многослойных покрытий.
\end{abstract}

Ключевые слова: многослойные и многокомпонентные покрытия, износ, вязкость разрушения, твердость.

Introduction. Improvements in functional properties of tools and the reduction of ecological threats would be accomplished by employing the technology of putting down hard coatings. These coatings are such as TiN (titanium nitide) and TiC (titanium carbide) on tools that deposited by chemical vapor deposition (CVD), physical vapor deposition (PVD) and plasma assisted chemical vapor deposition (PACVD) processes [1]. Carbide ceramic materials (like TiC) offer extremely high hardness, but suffer from low ductility and fracture toughness, which have restricted their applications [2-4]. To improve their performance against the brittle failure in ceramic materials, strategies have been developed in recent years to design tough and strong ceramics, consisting of multilayer or multicomponent coatings. These strategies include tailoring of weak interfaces for the crack deflection or the design of multilayers with compressive residual stresses [5]. 
Different researchers have been studied TiC/TiN single and multilayer coatings that deposited by different techniques of the PVD [6-8]. Only some of these studies concerned about the PACVD technique. However, the PACVD could be a proper technique for depositing thin and hard multilayer coatings on different substrates. This is due to the possibility of achieving properties at low temperatures, high deposition rate and high throwing power even for parts with complex shape [9-11]. Properties such as the hardness of double layer coatings (TiN/TiC-2) (using the PACVD) were investigated by Kim et al. [8]. Takahashi and Shimada [12] prepared compositionally graded TiC/TiN-2 films by the liquid injection of PACVD. They studied the composition and the structure of graded TiC/TiN-2 films on silicon substrates. Kim et al. [13] deposited Ti(C,N) coatings on aluminum alloy substrates with the pulsed-DC PACVD, using diethyl-lamino-titanium as precursor. They reported that this coating showed $1100 \mathrm{VHN}$ in the Vickers hardness test. The scratch resistance of $\mathrm{Ti}(\mathrm{C}, \mathrm{N})$ coatings on the plasma nitrated substrate was also studied by He et al. [14]. The wear resistance, the hardness [15-17] and the nano behavior [18] of $\mathrm{Ti}(\mathrm{C}, \mathrm{N})$ coatings were evaluated by other researchers. The tribological behavior and wear mechanisms of TiN/TiCN/TiN multilayer coatings were also investigated by $\mathrm{Su}$ et al. [19]. Due to this literature review, there is a lack of sciences about comparing mechanical properties (like the fracture toughness) of the multilayer coatings with multicomponent coatings.

A necessary criterion for evaluating the brittleness of thin coatings is to measure the fracture toughness of coatings. For bulk materials and some thick films, the fracture toughness could be easily measured due to ASTM standards. Unlike bulk materials, there is neither standard procedure nor commonly accepted methodology to follow for thin films [20]. In such cases, the indentation technique might be considered as the most suitable technique. Since it requires only a small size of specimens and simple experimental procedures [10]. Thus as a first time, the measurement of mechanical properties such as the fracture toughness of TiN/TiC-n multilayer coatings and $\mathrm{Ti}(\mathrm{C}, \mathrm{N})$ multicomponent coatings has been done in this paper. Influences of the multilayer modulation period on the wear resistance and hardness characteristics of TiN/TiC-n and Ti(C,N) coatings, fabricated on hot work tool steel (H13) substrates by the PACVD, were investigated. The crystalline structure of coatings was determined by the field emission scanning electron microscopy (FE-SEM). Finally, mechanical properties of TiN/TiC-n and Ti(C,N) coatings were compared to the $\mathrm{TiC}$ single layer coating. The objective is to observe which of layering or compounding of coatings was effective to improve properties of the TiC single layer coating.

1. Materials and Methods. The used substrates in this research are AISI H13 hot work tool steel, with the hardness of 280 VHN. Its chemical composition (in weight percent) is listed in Table 1. Substrates were heat treated to increase the substrate hardness to $680 \mathrm{VHN}$. The heat treatment was including quenching and tempering in $500^{\circ} \mathrm{C}$. Then, Substrates were prepared by grinding up to 2000 grits. They were cleaned with an alkali solution in an ultrasonic bath at $100^{\circ} \mathrm{C}$ for $10 \mathrm{~min}$. In order to decrease the hardness difference of coatings with substrates and increase the adhesion of coatings to the substrates, a plasma nitriding operation [21-23] was performed. Then, the surface hardness of substrates reached to $1000 \mathrm{VHN}$.

$\mathrm{T}$ a b 1 e 1

Chemical Composition of the Substrate

\begin{tabular}{|c|c|c|c|c|c|c|c|c||}
\hline $\mathrm{C}$ & $\mathrm{Si}$ & $\mathrm{Cr}$ & $\mathrm{Mo}$ & $\mathrm{V}$ & $\mathrm{Mn}$ & $\mathrm{Ni}$ & $\mathrm{Cu}$ & $\mathrm{Fe}$ \\
\hline 0.45 & 0.69 & 5.72 & 1.14 & 2.23 & 0.27 & 0.15 & 0.24 & balance \\
\hline
\end{tabular}

TiN/TiC-n multilayer, TiC and $\mathrm{Ti}(\mathrm{C}, \mathrm{N})$ single layer coatings were deposited in a PACVD reactor. $\mathrm{TiCl}_{4}$ as a precursor with $\mathrm{H}_{2}, \mathrm{Ar}, \mathrm{CH}_{4}$, and $\mathrm{N}_{2}$ gases were used. The 
working pressure of the chamber was 2-6 mbar. The working area of the chamber is $500 \times 700 \mathrm{~mm}$ (diameter $\times$ height) and a pulsed-DC power supply was used to trigger the plasma. Details about other experimental conditions were mentioned in the other our research $[21,24,25]$. In multilayer coatings, the TiN layer was firstly deposited due to have a better adhesion to the substrate [26]. The thickness of each layer in multilayer coatings was controlled by adjusting the feeding time of reactant gases. The thickness of all coatings was about $2.5 \pm 0.5 \mu \mathrm{m}$. The thickness of each layer in multilayer coatings could be calculated by dividing the total thickness to the number of layers.

The hardness of the coatings was measured on their top surfaces by a Vickers hardness tester under the load of $0.25 \mathrm{~N}$. Friction and wear behaviors of samples were evaluated using a pin-on-disk wear test. In all wear tests, the used pin of was WC-6wt.\% Co ( $5 \mathrm{~mm}$ of the diameter) that subjected to coating surfaces. The hardness of the ball was about 24-27 GPa. The rotating velocity was $0.1 \mathrm{~m} / \mathrm{s}$ and the rotating radius was $40 \mathrm{~mm}$. Total wear distance was $1000 \mathrm{~m}$ and the applied force was $10 \mathrm{~N}$. The wear testing was performed at room temperature without using a lubricant. The averaged value of three measurements was reported for the wear and the hardness test. The Vickers hardness tester was also used on the surface of TiN/TiC-n multilayer coatings, considering 10-2500 N of the load to determine the fracture toughness of coatings. It should be noted that the fracture toughness encompasses the energy, which requires both to create the crack and to enable the crack to propagate until the fracture. However, the fracture toughness takes only account for the energy, which requires facilitating the crack propagation to the fracture [27]. Indent and crack dimensions were measured using an optical microscope. Measured values of the crack length $(l)$ and the half-length of the diagonal indent $(a)$ were used to calculate the fracture toughness $\left(K_{c}\right)$.

The length of radial cracks propagating from the corners is used to estimate the fracture toughness of the ceramic coating due to the following equation (1):

$$
K_{c}=0.0089\left(\frac{E}{H}\right)^{2 / 5} \frac{P}{a l^{1 / 2}},
$$

where $E$ is the elastic modulus, $H$ is the Vickers hardness, $P$ is the applied load, $a$ is the half-length of the diagonal indent, and $l$ is the radial crack length [4]. The ratio of $E / H$, can be eliminating which is showed material characteristics, as Eq. (2) [28],

$$
K_{c}=0.0319 \frac{P}{a l^{1 / 2}} \text {. }
$$

Due to the Eq. (2), the fracture toughness could be measured by the slope of the diagram, which is the load $P$ versus $a l^{1 / 2}$.

\section{Results and Discussion.}

2.1. Microstructure. The FE-SEM images of cross section of coatings were shown in Fig. 1. The morphology of all coatings demonstrated a fine equiaxed grained structure. However, theses coatings, which were deposited by the PVD [13, 17], had a columnar structure. The interface between coatings and substrates was continuous with minimum pores and defects. This indicates good adhesive and bonding properties. As seen in Fig. 1a, some holes were observed in $\operatorname{Ti}(\mathrm{C}, \mathrm{N})$ single layer coatings. Due to this structure, the prediction of lower hardness and lower fracture toughness (especially under higher applied forces) of this coating was possible. As the number of layers increased (from 2 to 10 layers), coatings had smaller grain structures and the structure became increasingly denser, as it was reported by Liu et al. [29]. Therefore, minimum defects were appeared in multilayers coatings with respect to single layer coatings. The interface between TiN layers 
and TiC layers in multilayer coatings is not quite sharp (Fig. 1b and 1c) and the existence of these interfaces can reduce the internal stress of the film [4]. As shown in Fig. 1d, the image demonstrates that even the substrate surface was not completely flat; coatings were deposited uniformly on rough surfaces. This is due to high power throwing in the PACVD process. This unique property is related just to the PACVD technique.

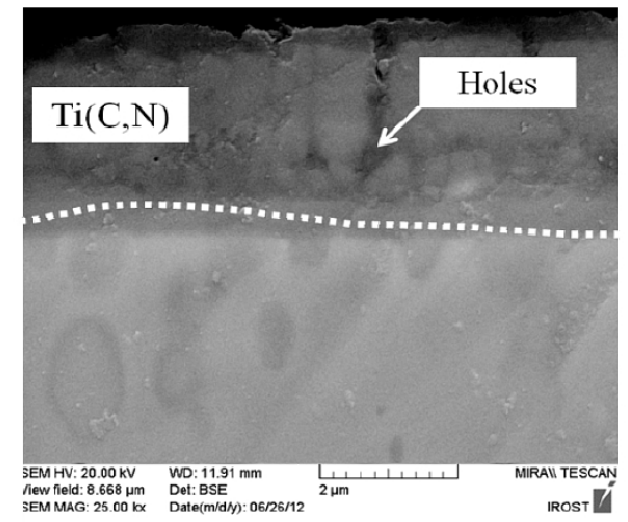

a

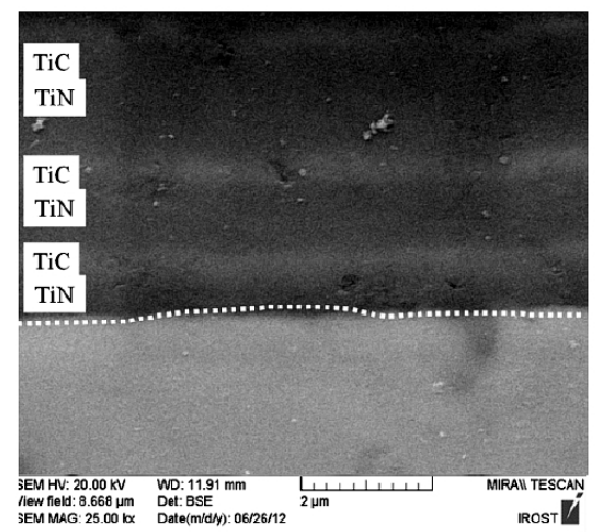

$\mathrm{c}$

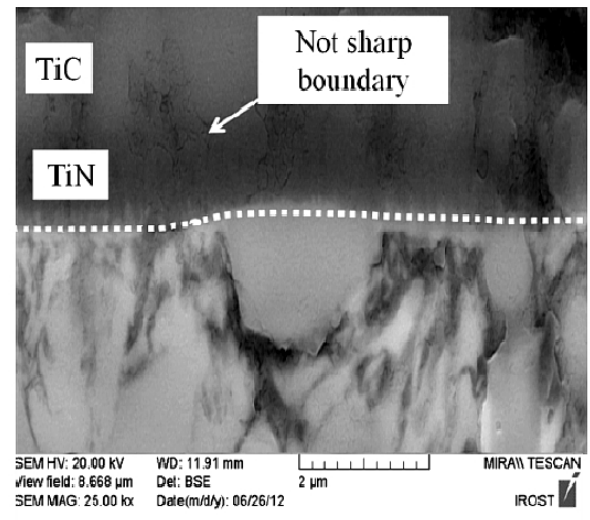

b

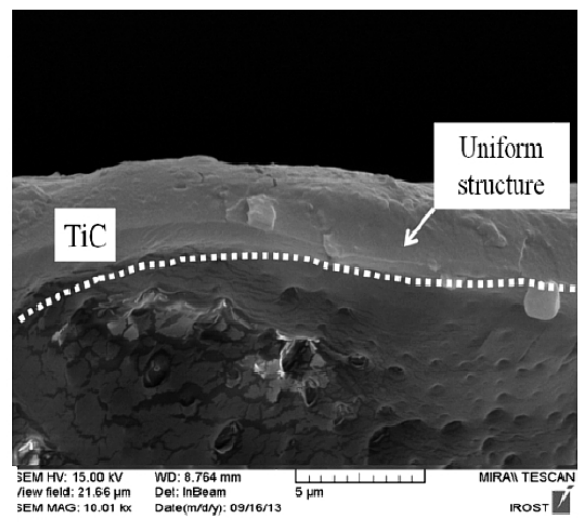

d

Fig. 1. Cross section FE-SEM images for coatings-substrates: (a) Ti(C,N); (b) TiN/TiC-2; (c) TiN/ TiC-6; (d) TiC coatings.

2.2. Hardness. The material hardness is depended on many factors such as interatomic bond lengths, the degree of covalent bonding, the temperature, the microstructure and the deformation mechanism $[30,31]$. As the microstructure and the deformation mechanism were different for $\mathrm{TiC}, \mathrm{Ti}(\mathrm{C}, \mathrm{N})$ single layer coatings and TiN/TiC multilayer coatings, the changes in the hardness of theses coatings with the same crystal structure was predictable. The hardness of $\mathrm{TiC}$ and $\mathrm{Ti}(\mathrm{C}, \mathrm{N})$ single layer coatings was 3000 and $2700 \mathrm{VHN}$, respectively. In addition, the hardness of $\mathrm{Ti}(\mathrm{C}, \mathrm{N})$ single layer coatings was reported 1100 VHN GPa, when it was deposited on the aluminum substrate [13]. The enhancement of the hardness for TiN/TiC-10 coatings was approximately 5-20\% with respect to $\mathrm{TiC}$ and $\mathrm{Ti}(\mathrm{C}, \mathrm{N})$ single layer coatings. Results in Table 2 show that reducing the individual layer thickness for multilayer coatings resulted in increasing the coatings hardness. The hardness enhancement for TiN/TiC-n multilayer coatings would be contributed to the inhibition of the dislocation formation and its mobility and blocking [32]. Dislocation blocking occurs when the two layers of the multilayer have different shear modulus, and therefore different 
dislocation line energies. In this case, dislocations prefer to remain within the layer with the lower shear modulus. An additional stress is required to move the dislocation into the layer with the higher shear modulus compared to the stress required to move the dislocation in a layer with the lower shear modulus [33]. Thus, as the difference of shear modulus of TiN and $\mathrm{TiC}$ was not high, the $5-20 \%$ change in hardness between single and multilayer coatings was reasonable.

$\mathrm{T}$ a b 1 e 2

Mechanical Properties of Coatings

\begin{tabular}{|c|c|c|c|c||}
\hline Sample & $\begin{array}{c}\text { Microhardness } \\
(\mathrm{VHN})\end{array}$ & $\begin{array}{c}\text { Specific } \\
\text { wear rate } \\
\left(\mathrm{mm}^{3} / \mathrm{N} \cdot \mathrm{m}\right) \cdot 10^{-7}\end{array}$ & $\begin{array}{c}\text { Friction } \\
\text { coefficient }\end{array}$ & $\begin{array}{c}\text { Fracture } \\
\text { toughness } \\
\left(\mathrm{MPa} \cdot \mathrm{m}^{1 / 2}\right)\end{array}$ \\
\hline $\mathrm{Ti}(\mathrm{C}, \mathrm{N})$ & $2700 \pm 50$ & $3.00 \pm 0.05$ & $0.35-0.40$ & 10.6 \\
\hline $\mathrm{TiN} / \mathrm{TiC}-2$ & $3050 \pm 50$ & $4.60 \pm 0.05$ & $0.20-0.35$ & 14.1 \\
\hline $\mathrm{TiN} / \mathrm{TiC}-6$ & $3100 \pm 50$ & $0.11 \pm 0.05$ & $0.20-0.25$ & 14.5 \\
\hline $\mathrm{TiN} / \mathrm{TiC}-10$ & $3150 \pm 50$ & $0.05 \pm 0.05$ & $0.10-0.20$ & 17.7 \\
\hline $\mathrm{TiC}$ & $3000 \pm 50$ & $3.25 \pm 0.05$ & $0.10-0.15$ & 13.2 \\
\hline
\end{tabular}

2.3. Fracture Toughness. The cracks which form as a result of Vickers indentation are well developed radial/median cracks (sometimes referred to as half-penny cracks) and radial Palmqvist cracks [34]. In Palmqvist mode crack are originating near the edge of the plastic zone beneath the indent. In the radial-median mode derives from sub-surface median cracks that initiate along edges of the pyramidal indentation and extend deep into the material in a semi-circular manner, perpendicular to the surface. The possibility of a transition in the cracking mode (from the Palmqvist mode to the radial-median mode) is a function of the indentation load and the $/ / a$ ratio [27]. By measuring the $l / a$ ratio in this paper, the crack mode in all samples was the Palmqvist crack, even the load increased from 10 to $2500 \mathrm{~N}$. This result was also reported by Holleck [35]. The summation of crack lengths and the half-length of the diagonal indent $\left(a l^{1 / 2}\right)$ were measured as a function of the applied load. Results are shown in Fig. 2.

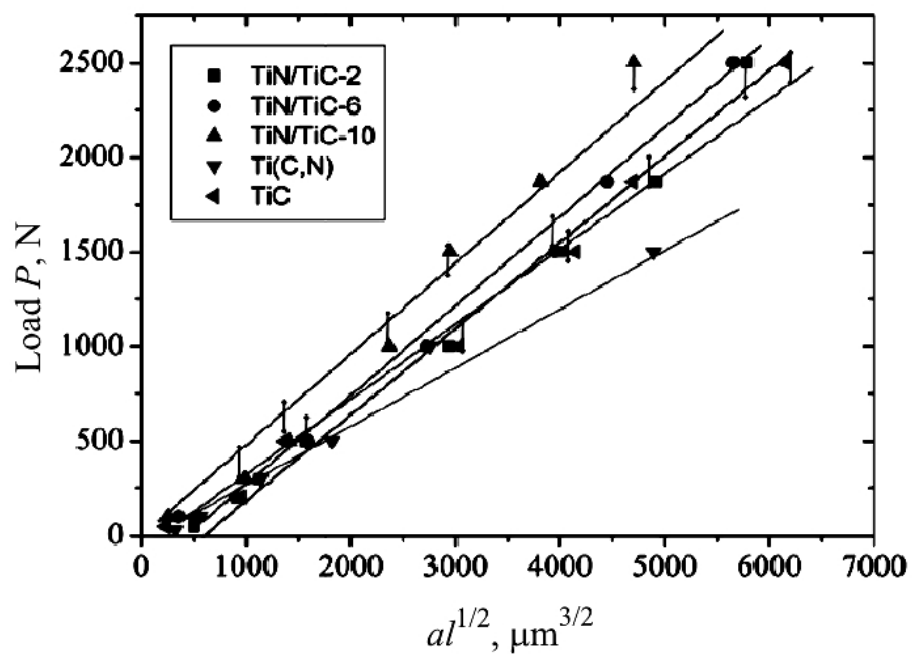

Fig. 2. The load $P$ versus $a l^{1 / 2}$ for samples for multilayer and multicomponent coatings. 
As the fracture toughness is depended on the applied force, slopes of the $P-a l^{1 / 2}$ diagram were considered for comparing the coatings fracture toughness $[21,36]$. When the applied force was under $500 \mathrm{~N}$, the slope of this diagram for Ti $(\mathrm{C}, \mathrm{N})$ single layer coatings was more than that one for TiC single layer coatings. As the applied force increased from 500 to $2500 \mathrm{~N}$, Ti(C,N) single layer coatings had lower fracture toughness with respect to TiC single layer coatings. Thus, in all due to the slope of the curve, Ti(C,N) single layer coatings had the minimum fracture toughness (as $10.6 \mathrm{MPa} \cdot \mathrm{m}^{1 / 2}$ ) among other coatings. The minimum critical load to cracking was also related to $\operatorname{Ti}(\mathrm{C}, \mathrm{N})$ single layer coatings and its value was reported as $10 \mathrm{~N}$. As shown in Table 2, in multilayer coatings, the fracture toughness increased as the number of layers increased from 14.1 to $17.7 \mathrm{MPa} \cdot \mathrm{m}^{1 / 2}$. When the number of layers increased from 2 to 10 layers, the critical load to cracking also increased from 50 to $100 \mathrm{~N}$.

Figure 3 shows results, deduced from indentation experiments and performed on the surface of coatings, when the applied forced was $1500 \mathrm{~N}$. In $\mathrm{Ti}(\mathrm{C}, \mathrm{N})$ single layer coatings, the half-length of the diagonal indent was higher than those values in other coatings, due to the lower hardness. When the applied force increased, the half-length of the diagonal indent, both the total crack length and crack branches increased. The presence of concentric ring cracks in $\mathrm{Ti}(\mathrm{C}, \mathrm{N})$ single layer coatings were minimum and the residual Vickers impression showed in irregular lines despite of other coatings. As shown in Fig. 3b and 3c, cracks for multilayer coatings were generated at corners of Vickers indentations. This was also reported by Nolan et al. [28]. As the number of layers in multilayer coatings increased from 2 to 10, the diameter of concentric ring cracks and the number of them increased. When the number of layers reached to 10 layers, the total crack length and concentric ring decreased, as demonstrated in Fig. 3d. Due to the Holleck [35] illustration, improvements in the indentation fracture toughness for multilayers coating were related to the crack deflection in the interfaces and stress relaxation mechanisms.

2.4. Wear Properties. For comparing the wear resistance of coatings, we used Landcaster formulation [37] to report the specific wear rate in the fixed wear condition such as the applied load, the environment (the relative humidity and the lubricity of the contact surface), the sliding speed and the temperature. This formulation has proven to be useful for the comparison of the wear behavior between different materials [38, 39]. Table 2 represents the comparison of wear volume after the wear distance of $1000 \mathrm{~m}$. The wear volume for all coatings was low due to the relatively high hardness of coatings. Thus as the hardness of multilayer coatings increased the wear resistance increased (or their wear rate decreased).

The size and number of holes, pits, cracks and discontinuity in wear track produced by the abrasive pin wear, offers a relation to observe the wear loss of specimens [11]. The wear volume of TiN/TiC-10 coatings was approximately one-hundredth that of $\mathrm{Ti}(\mathrm{C}, \mathrm{N})$ single layer coatings.

Both values of the hardness and the wear resistance, as expected, were become highest in TiN/TiC-10 coatings. While in $\mathrm{Ti}(\mathrm{C}, \mathrm{N})$ coatings, the hardness value was lower. In addition, $\mathrm{Ti}(\mathrm{C}, \mathrm{N})$ coatings had better wear resistance with respect to $\mathrm{TiC}$ coatings. This trend was also shown by the literature [31] due to different wear mechanisms. The wear resistance of $\mathrm{TiN} / \mathrm{TiC}$ multilayer coatings was remarkably improved by increasing the number of layers. The improved wear resistance for TiN/TiC multilayer coatings, compared to $\mathrm{Ti}(\mathrm{C}, \mathrm{N})$ single layer coatings, was contributed by several factors. These factors include the enhancement of the hardness, the fracture toughness (due to the presence of interfaces in multilayer coatings) and the plastic deformation [40, 41]. By increasing the hardness and the fracture toughness of multilayer coated samples, the wear resistance increased with respect to single layer coatings of $\mathrm{Ti}(\mathrm{C}, \mathrm{N})$ and $\mathrm{TiC}$. 


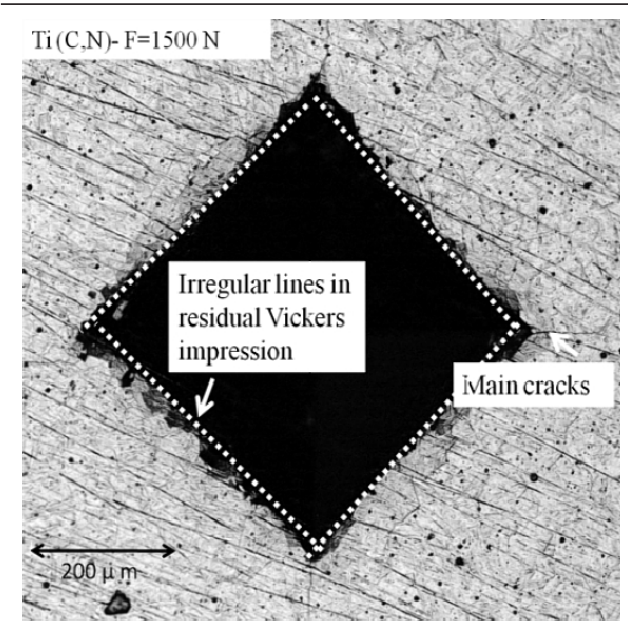

a

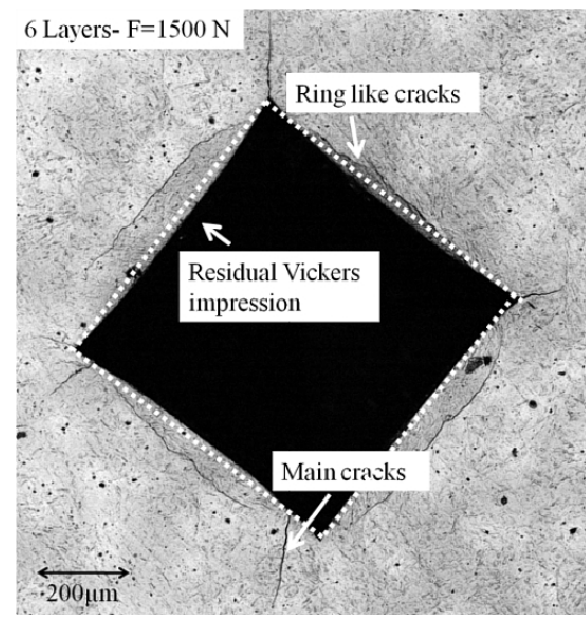

c

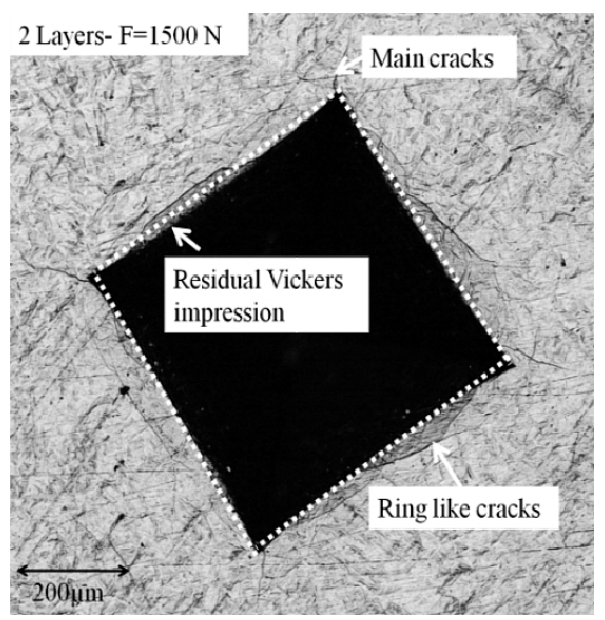

b

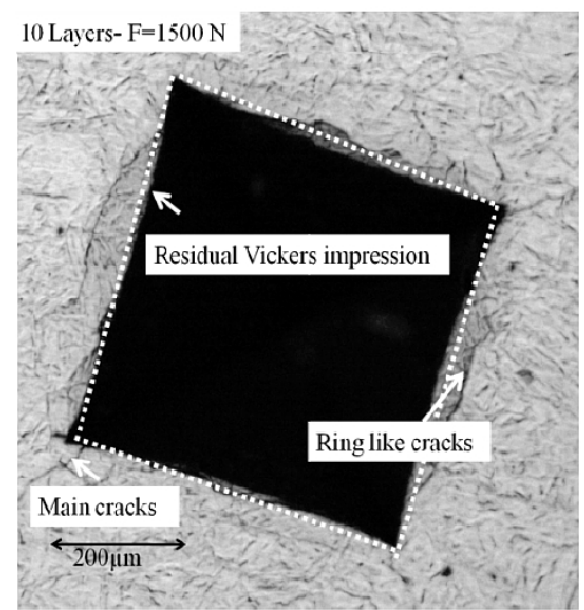

d

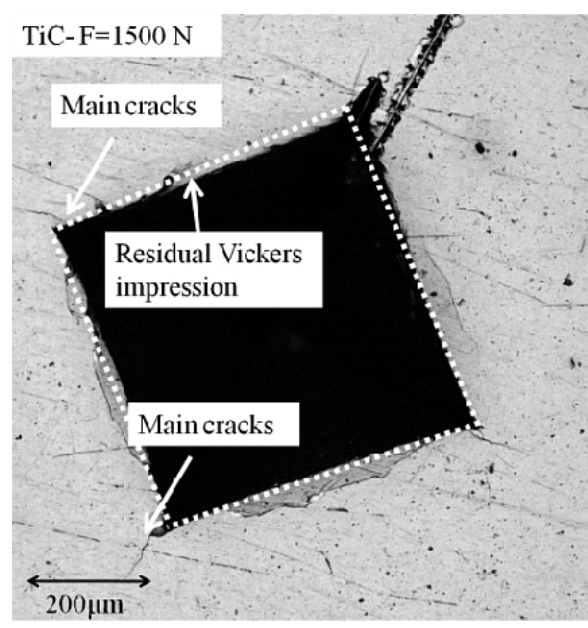

e

Fig. 3. Results deduced from the indentation, performed on the surface of coatings with the applied forced of $1500 \mathrm{~N}$ : (a) Ti(C,N); (b) TiN/TiC-2; (c) TiN/TiC-6; (d) TiN/TiC-10; (e) TiC coatings. 
2.5. Wear Mechanism. As wear conditions were constant for all samples in this research, the wear mechanism was dependent on the nature of materials and mechanical characteristics of surfaces. Due to the speed of the wear (as $0.1 \mathrm{~m} / \mathrm{s})$ and the images in the Fig. 4, the mechanical mechanism was a dominant mode of the wear for all samples. As, it was mentioned by Jianxin et al. [42], the minimum speed for the chemical wear mechanism in these coatings was $1.5 \mathrm{~m} / \mathrm{s}$ to produce high temperature (about $500^{\circ} \mathrm{C}$ ) to form $\mathrm{TiO}_{2}$. In mechanical wear mechanism, the fractured small ceramic particles from coatings on the surface of specimens can act like the secondary moving indenters [43].

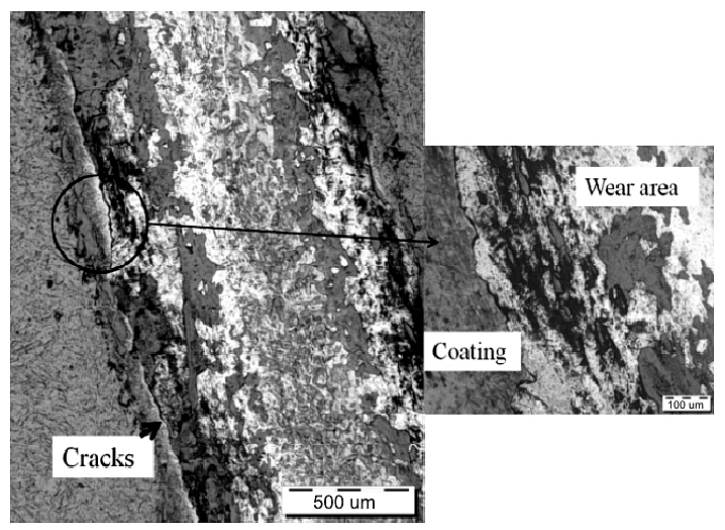

a

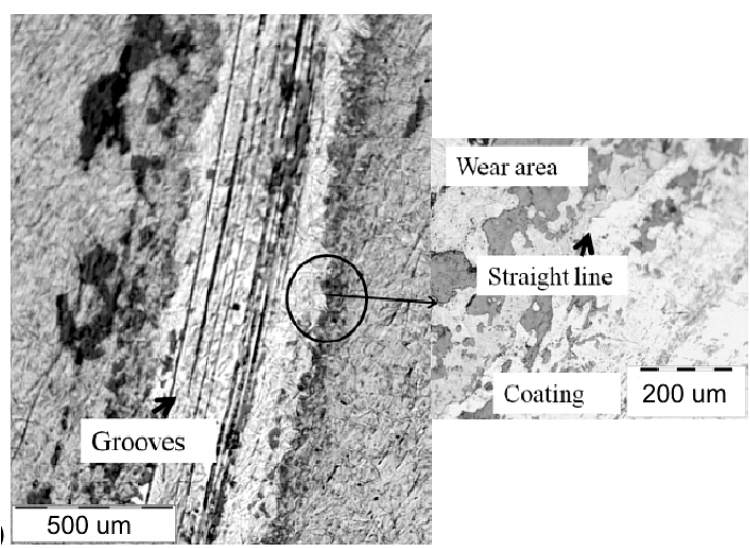

b

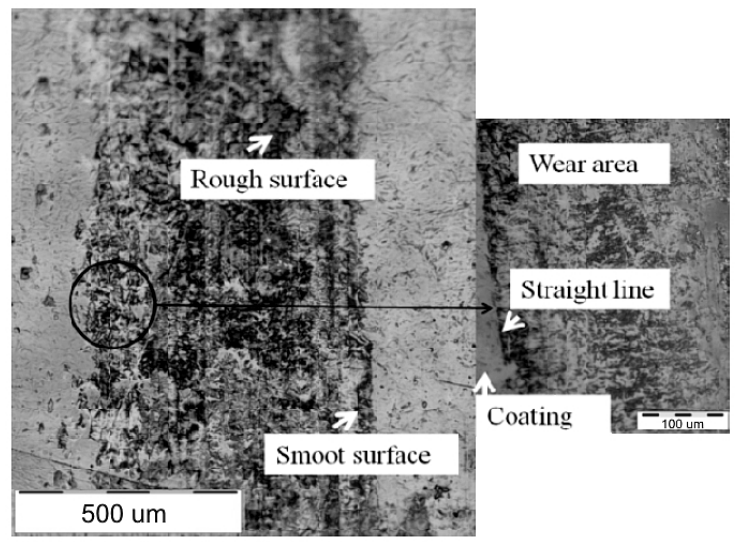

c 


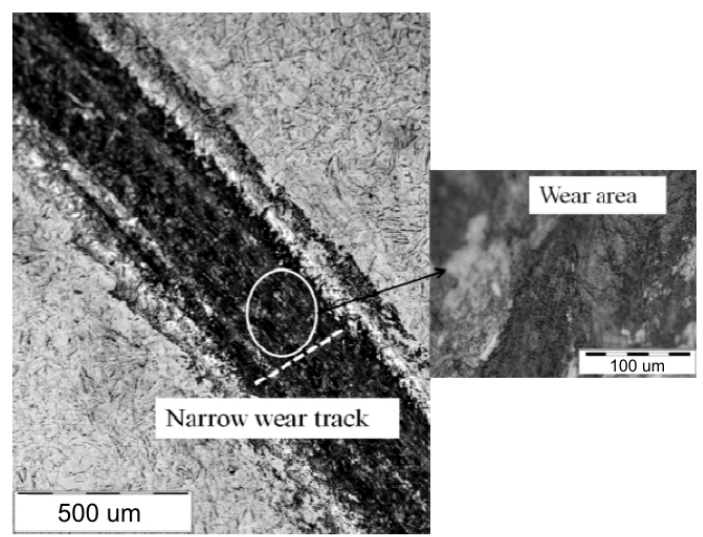

d

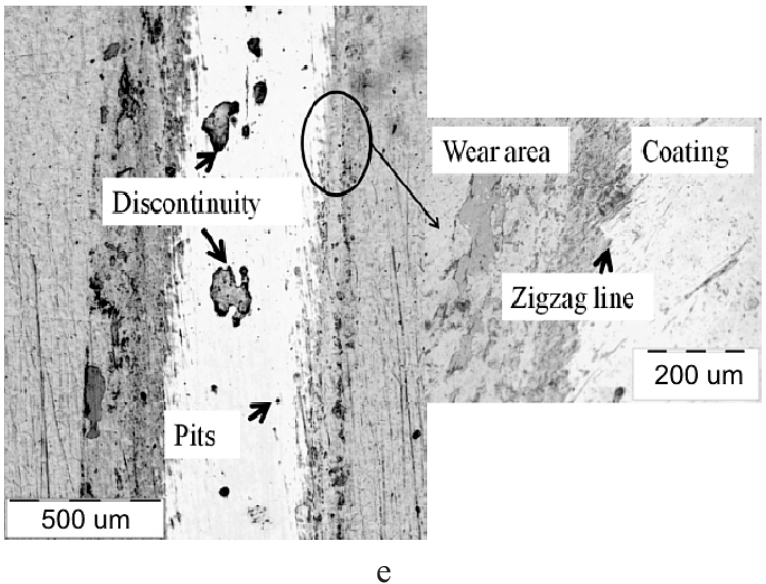

Fig. 4. The wear surface topography: (a) Ti(C,N); (b) TiN/TiC-2; (c) TiN/TiC-6; (d) TiN/TiC-10; (e) TiC coatings.

Optical micrographs of wear tracks from coatings are presented in Fig. 4 after the sliding of $1000 \mathrm{~m}$. Ti(C,N) layers of coating seem to be twisted and compressed together. In the wear tract there were some cracks. This can be clearly seen in Fig. 4a. The formation of cracks maybe related to the presence of fractured ceramic particles on the wear tract as mentioned by other researches [43]. Wear tracks of $\mathrm{Ti}(\mathrm{C}, \mathrm{N})$ single layer coatings showed a very irregular surface with much discontinuity beside wear track. This was also observed by other researches [14]. The width of the worn scar was the highest among other coatings and was measured about $1200 \mu \mathrm{m}$. This behavior was also seen in TiN single layer coatings that were deposited by the PVD $[8,44]$. The wear mechanism in this coating was combination of the adhesion (shear ploughing) and the deformation with low elastic recovery.

Worn surfaces of multilayer coatings consisted of following main regions: the smooth area, the area containing very small discontinuity and surface fractures, as reported by Pirso et al. [38] and as seen in Fig. $4 \mathrm{~b}$ to $4 \mathrm{~d}$. The surface of specimens revealed a combination of polished and rough regions. Presence of pits, holes and cracks were at least and the separation of the layers from each other were seen in some local places in the wear track. For TiN/TiC multilayer coatings, the depth of grooves were decreased by increasing the number of layers. These grooves seem to be faded for TiN/TiC-10 multilayer coatings. Wear tracks for multilayer coatings were separated by almost straight lines. The wear 
mechanism in multilayer coatings was small-scale cutting and ploughing. As presented by Liu et al. [29], the wear depth and the wear width of coatings decreased by increasing the number of layers. The wear width of TiN/TiC-10 multilayer coatings was less than $500 \mu \mathrm{m}$. In this paper, due to the low sliding speed, adhesions or large-scale spalling of coatings were not formed on specimens as mentioned by other researchers $[39,45]$.

TiC single layer coatings showed a more uniform wear track than $\mathrm{Ti}(\mathrm{C}, \mathrm{N})$ single layer coatings in Fig. 4e. Worn surfaces of TiC coated samples had small pits that outspreaded in the wear track. The wear track for TiC single layer coatings were separated by zigzag lines. The wear mechanism for TiC single layer coatings was cutting or scratching. In the cutting mode, the narrow and surface scratches were seen [44]. The wear mechanism for TiC single layer coatings was qualitatively consistent with other results, as reported by Martinez et al. [46].

2.6. Friction Coefficient. Figure 5 demonstrates friction coefficient of coatings, as a function of the wear distance.

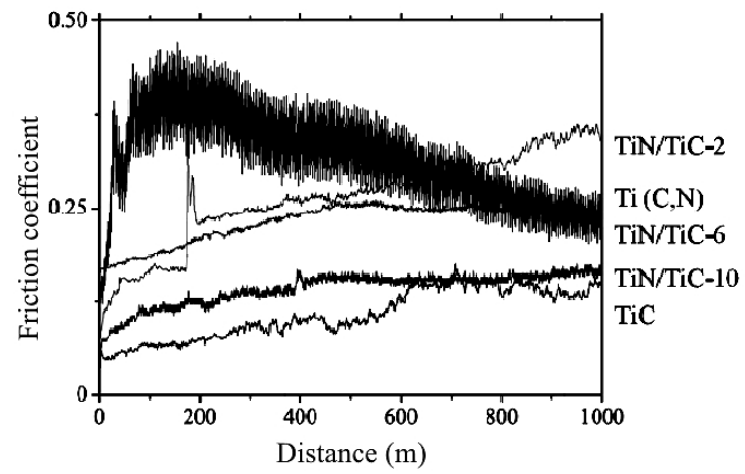

Fig. 5. The friction coefficient versus the time for single layer and multilayer coatings.

For all samples, except $\mathrm{Ti}(\mathrm{C}, \mathrm{N})$ single layer coatings, the level of the friction coefficient had almost a linear increase until a stable level of the friction coefficient was reached. The reason was reported by Bao et al. [47]. He claimed that the effective contact area was very limited in initial times of wear sliding. Therefore, low friction coefficient was observed in this starting period, due to lower friction resistance. After that, the effective contact area increased gradually by the wear times in which the friction coefficient varied from its lower initial value to a relatively higher stable value. The literature [47] also indicated that the generation of wear pits and the discontinuities took place on the surface, contributed significantly to the increasingly high friction coefficient. Graphs for Ti(C,N) single layer coatings with large ranges was also observed by Forn et al. [48]. This was due to the different wear mechanism.

Friction coefficient values are listed in Table 2. Friction coefficients were average values over the whole sliding duration of $1000 \mathrm{~m}$. Friction coefficient values, which were measured in this test, were greater than 0.15 , reaching a maximum value of 0.4 for $\operatorname{Ti}(\mathrm{C}, \mathrm{N})$ coatings. In the steady-state friction stage, TiC single layer coatings showed much lower friction coefficient than that one in $\operatorname{Ti}(\mathrm{C}, \mathrm{N})$ coatings, as reported by Martinez et al. [46]. The average value of the friction coefficient in TiC single layer coatings (as 0.18 ) was a little smaller than the value of 0.23 , found in the literature for TiC single layer coatings [21, 49], that was deposited by means of high temperature CVD [22]. The increase in the number of layers in multilayers coatings resulted in the decrease of the friction coefficient, as mentioned by other researches [29, 50]. The hardness, the fracture toughness, the structure, the composition and other properties of coatings had effects on the friction coefficient [51]. As showed, the decrease of the thickness of each layer in multilayer 
coatings caused the increase in the hardness and in the fracture toughness. As a result, the friction coefficient increased.

Conclusions. TiN/TiC-n multilayer and $\mathrm{Ti}(\mathrm{C}, \mathrm{N})$ mutlicomponent coatings were deposited by the pulsed-DC PACVD. High hardness about 1150 VHN was observed for TiN/TiC-10 multilayer coatings. Its friction coefficient was lower as 0.2 and its fracture toughness was higher as $17.7 \mathrm{MPa} \cdot \mathrm{m}^{1 / 2}$. The enhancement in the hardness of multilayer coatings with respect to single layer coatings was attributed to several interfaces that blocked the dislocation movement across the interface between TiC and TiN layers. When the number of layers in multilayer coatings increased, the wear resistance increased and the friction coefficient decreased due to the high hardness and the high fracture toughness. In addition, compounding coatings was also effective for improving the wear resistance of TiC single layer coatings. The wear mechanism changed from ploughing for $\mathrm{Ti}(\mathrm{C}, \mathrm{N})$ single layer coatings into cutting for TiC single layer coatings.

\section{Резюме}

Вивчено механічні властивості багатошарових і багатокомпонентних покриттів. Багатошарове нітрид-титанове/карбід-титанове (TiN/TiC-n) і багатокомпонентне Ti(C,N) покриття наносили на поверхню гарячеобробленої інструментальної сталі AISI H13 за допомогою вакуум-плазмового хімічного осадження пара при дії імпульсного постійного струму. Досліджено мікротвердість, в'язкість руйнування, руйнування при зношенні і коефіцієнт тертя при випробуваннях на твердість за Віккерсом та зношення за схемою “диск-шпилька”. Поверхні, що зазнали зношення, та механізми зношення вивчали за допомогою оптичного мікроскопа. Результати показують, що багатошарові покриття TiN/TiC-10 мають більш низькі значення коефіцієнта тертя $(0,2)$ і руйнування при зношенні та більш високі значення в'язкості руйнування $\left(17,7 \mathrm{MПа} \cdot \mathrm{M}^{1 / 2}\right)$ і мікротвердості (3150 VHN) порівняно $з$ такими для багатокомпонентного покриття Ti(C,N) й інших досліджуваних багатошарових покриттів.

1. L. Dobrzański, K. Gołombek, J. Mikuła, and D. Pakuła, "Multilayer and gradient PVD coatings on the sintered tool materials," J. Achiev. Mater. Manuf. Eng., 31, No. 2, 170-190 (2008).

2. F. Kustas, B. Mishra, and J. Zhou, "Fabrication and characterization of $\mathrm{TiB}_{2} / \mathrm{TiC}$ and tungsten co-sputtered wear coatings," Surf. Coat. Technol., 153, 25-30 (2002).

3. E. Pagounis, V. K. Lindroos, "Development and performance of new hard and wear-resistant engineering materials," J. Mater. Eng. Perform., 6, 749-756 (1997).

4. M. Azadi, A. S. Rouhaghdam, and S. Ahangarani, "Properties of TiC coating by pulsed DC PACVD," J. Coat., 2013, 1-5 (2013), Article ID 712812.

5. C. R. Chen, J. Pascual, F. D. Fischer, et al., "Prediction of the fracture toughness of a ceramic multilayer composite - Modeling and experiments," Acta Mater., 55, 409421 (2007).

6. A. Roman, D. Chicot, and J. Lesage, "Indentation tests to determine the fracture toughness of nickel phosphorus coatings," Surf. Coat. Technol., 155, 161-168 (2002).

7. A. Devia, V. Benavides, E. Restrepo, et al., "Influence substrate temperature on structural properties of TiN/TiC bilayers produced by pulsed arc techniques," Vacuum, 81, 378-384 (2006).

8. L. Zhang, H. Yang, X. Pang, et al., "TiN-coating effects on stainless steel tribological behavior under dry and lubricated conditions," J. Mater. Eng. Perform., 23, 12631269 (2014). 
9. D. Kim, Y. Cho, M. Lee, et al., "Properties of TiN-TiC multilayer coatings using plasma-assisted chemical vapor deposition," Surf. Coat. Technol., 116-119, 906-910 (1999).

10. A. Shanaghi, A. S. Rouhaghdam, S. Ahangarani, and P. K. Chu, "Effect of plasma CVD operating temperature on nanomechanical properties of TiC nanostructured coating investigated by atomic force microscopy," Mater. Res. Bull., 47, 2200-2205 (2012).

11. H. L. Wang, J. L. He, and M. H. Hon, "Sliding wear resistance of TiCN coatings on tool steel made by plasma-enhanced chemical vapour deposition," Wear, 169, 195200 (1993).

12. M. Takahashi and S. Shimada, "Preparation of composite and compositionally graded TiC-TiN films by liquid injection plasma-enhanced CVD," Solid State Ionics, 172, 249-252 (2004).

13. S. K. Kim, T. H. Kim, J. Whöle, and K.-T. Rie, "TiCN coatings on aluminum alloy formed by MO-PACVD," Surf. Coat. Technol., 131, 121-126 (2000).

14. Y. He, I. Apachitei, J. Zhou, et al., "Effect of prior plasma nitriding applied to a hot-work tool steel on the scratch-resistant properties of PACVD TiBN and TiCN coatings," Surf. Coat. Technol., 201, No. 6, 2534-2539 (2006).

15. Y. He, I. Apachitei, J. Zhou, et al., "The influence of the depth of a plasma nitrided layer in tool-steel substrate on the scratch-resistant properties of PACVD TiBN coating," Surf. Coat. Technol., 201, No. 16-17, 7036-7042 (2006).

16. I. Dörfel, W. Österle, I. Urban, et al., "Microstructural characterization of binary and ternary hard coating systems for wear protection. Part II: Ti(CN) PACVD coatings," Surf. Coat. Technol., 116-119, 898-905 (1999).

17. S. Ma, K. Xu, and W. Jie, "Plasma nitrided and TiCN coated AISI H13 steel by pulsed dc PECVD and its application for hot-working dies," Surf. Coat. Technol., 191, 201-205 (2005).

18. W. Feng, H. Zhou, and S. Yang, "Nano-indentation and wear-resistance behaviors of TiCN films by pulsed plasma on cemented carbide cutting tool," Mater. Sci. Eng. A, 527, 4767-4770 (2010).

19. Y. L. Su and W. H. Kao, "Tribological behavior and wear mechanisms of TiN/ TiCN/TiN multilayer coatings," J. Mater. Eng. Perform., 7, 601-612 (1998).

20. C. Y. H. Lim, S. C. Lim, and K. S. Lee, "Wear of TiC-coated carbide tools in dry turning," Wear, 225-229, 354-367 (1999).

21. M. Azadi, A. S. Rouhaghdam, S. Ahangarani, and H. H. Mofidi, "Mechanical behavior of TiN/TiC multilayer coatings fabricated by plasma assisted chemical vapor deposition on AISI H13 hot work tool steel," Surf. Coat. Technol., 245, 156-166 (2014).

22. M. S. Mahdipoor, F. Mahboubi, S. Ahangarani, et al., "The influence of plasma nitriding pre-treatment on tribological properties of TiN coatings deposited by PACVD,” J. Mater. Eng. Perform., 21, 958-964 (2012).

23. A. S. Korhonen and E. Harju, "Surface engineering with light alloys - Hard coatings, thin films, and plasma nitriding," J. Mater. Eng. Perform., 9, 302-305 (2000).

24. M. Azadi, A. S. Rouhaghdam, S. Ahangarani, et al., "Mechanical behavior and properties of TiN/TiC coating using PACVD," Adv. Mater. Res., 829, 476-482 (2014).

25. M. Azadi, A. S. Rouhaghdam, S. Ahangarani, et al., "Effect of number of layers on the toughness of TiN/TiC multilayer coatings," Int. J. Microstruct. Mater. Prop., 9, 500-515 (2014). 
26. Y. Zhao, G. Lin, J. Xiao, et al., "TiN/TiC multilayer films deposited by pulse biased arc ion plating," Vacuum, 85, 1-4 (2010).

27. R. Venkataraman and R. Krishnamurthy, "Evaluation of fracture toughness of as plasma sprayed alumina-13 wt.\% titania coatings by micro-indentation techniques," $J$. Eur. Ceram. Soc., 26, 3075-3081 (2006).

28. D. Nolan, V. Leskovsek, M. Jenko, "Estimation of fracture toughness of nitride compound layers on tool steel by application of the Vickers indentation method," Surf. Coat. Technol., 201, 182-188 (2006).

29. C. Liu, K. Liu, H. Yan, et al., "Mechanical properties of TiN/NbN multilayered films prepared by PVD coating," Adv. Ceram. Sci. Eng., 2, 16-22 (2013).

30. T. A. Rawdanowicz, V. Godbole, J. Narayan, et al., "The hardnesses and elastic moduli of pulsed laser deposited multilayer AlN/TiN thin films," Composites Part B: Eng., 30, 657-665 (1999).

31. A. Kumar, H. L. Chan, and N. B. Dahotre, "Structural and hardness studies of $\mathrm{CN}_{\mathrm{X}} / \mathrm{TiN}$ composite coatings on $\mathrm{Si}(100)$ substrates by laser ablation method," $J$. Mater. Eng. Perform., 6, 583-585 (1997).

32. C. A. Freyman and Y. W. Chung, "Synthesis and characterization of hardnessenhanced multilayer oxide films for high-temperature applications," Surf. Coat. Technol., 202, 4702-4708 (2008).

33. P. C. Yashar and W. D. Sproul, "Nanometer scale multilayered hard coatings," Vacuum, 55, 179-190 (1999).

34. J. Gong, "Determining indentation toughness by incorporating true hardness into fracture mechanics equations," J. Eur. Ceram. Soc., 19, 1585-1592 (1999).

35. H. Holleck, "Material selection for hard coatings," J. Vac. Sci. Technol. A, 4, No. 6, 2661-2669 (1988).

36. K. Holmberg, A. Matthews, and H. Ronkainen, "Coatings tribology - contact mechanics and surface design," Tribol. Int., 31, 107-120 (1998).

37. J. Lee, K. Euh, J. C. Oh, and S. Lee, "Microstructure and hardness improvement of $\mathrm{TiC} /$ stainless steel surface composites fabricated by high-energy electron beam irradiation," Mater. Sci. Eng. A, 323, 251-259 (2002).

38. J. Pirso, M. Viljus, and S. Letunovits, "Sliding wear of TiC-NiMo cermets," Tribol. Int., 37, 817-824 (2004).

39. Y. Y. Guu, J. F. Lin, and C. Ai, "The tribological characteristics of titanium nitride coatings. Part I. Coating thickness effects," Wear, 194, 12-21 (1996).

40. Y. M. Zhou, R. Asaki, K. Higashi, et al., "Sliding wear behavior of polycrystalline TiN/CrN multilayers against an alumina ball," Surf. Coat. Technol., 130, 9-14 (2000).

41. A. K. Keshri, V. Singh, J. Huang, et al., "Intermediate temperature tribological behavior of carbon nanotube reinforced plasma sprayed aluminum oxide coating," Surf. Coat. Technol., 204, 1847-1855 (2010).

42. J. Deng, T. Cao, and L. Liu, "Self-lubricating behaviors of $\mathrm{Al}_{2} \mathrm{O}_{3} / \mathrm{TiB}_{2}$ ceramic tools in dry high-speed machining of hardened steel," J. Eur. Ceram. Soc., 25, 1073-1079 (2005).

43. Z. Tong, C. Ding, and D. Yan, "A fracture model for wear mechanism in plasma sprayed ceramic coating materials," Wear, 155, 309-316 (1992).

44. A. J. Lockwood, S. Banfield, A. Leylandand, and B. J. Inkson, "Continuum roughness measurements of a TiN coating during dynamic in-situ wear inside a transmission electron microscope," in: Proc. EMC2012, Manchester, UK (2012). 
45. M. Scholl, "Abrasive wear of titanium nitride coatings," Wear, 203-204, 57-64 (1997).

46. E. Martinez, U. Wiklund, J. Esteve, et al., "Tribological performance of TiN supported molybdenum and tantalum carbide coatings in abrasion and sliding contact," Wear, 253, 1182-1187 (2002).

47. M. Bao, X. Xu, H. Zhang, et al., "Tribological behavior at elevated temperature of multilayer TiCN/TiC/TiN hard coatings produced by chemical vapor deposition," Thin Solid Films, 520, 833-836 (2011).

48. A. Forn, J. A. Pacas, G. G. Fuentes, and E. Elizalde, "Mechanical and tribological properties of $\mathrm{TiC}_{\mathrm{x}} \mathrm{N}_{1-\mathrm{x}}$ wear resistant coatings," Int. J. Refract. Met. Hard Mater., 19, 507-513 (2001).

49. C. Jarms, H. R. Stock, H. Berndt, et al., "Influence of the PACVD process parameters on the properties of titanium carbide thin films," Surf. Coat. Technol., 98, 1547-1552 (1998).

50. B. Warcholinski, A. Gilewicz, and P. Myslinski, "Tribological properties of TiAICrN thin films," Rev. Adv. Mater. Sci., 22, 81-88 (2009).

51. S. Novak, M. Kalin, P. Lukas, et al., "The effect of residual stresses in functionally graded alumina-ZTA composites on their wear and friction behaviour," J. Eur. Ceram. Soc., 27, 151-156 (2007). 